\title{
Analysis of Financial Fraud of Listed Company in China: A Case Study of Dandong Xintai Electric Co., Ltd.
}

\author{
Wei Zou \\ Department of Accounting, Management School, Jinan University, Guangzhou, China \\ Email: joey_zouwei@163.com
}

How to cite this paper: Zou, W. (2016) Analysis of Financial Fraud of Listed Company in China: A Case Study of Dandong Xintai Electric Co., Ltd. American Journa of Industrial and Business Management, 6, 931-941.

http://dx.doi.org/10.4236/ajibm.2016.69090

Received: August 30, 2016

Accepted: September 9, 2016

Published: September 12, 2016

Copyright $\odot 2016$ by author and Scientific Research Publishing Inc. This work is licensed under the Creative Commons Attribution International License (CC BY 4.0).

http://creativecommons.org/licenses/by/4.0/ (c) (i) Open Access

\begin{abstract}
With the development of China's economy, more and more malignant cases of financial fraud in China listed companies happen frequently, such as the financial frauds of Guangxia, green earth and Wanfu, which make a great impact on the normal operation of the securities market and the confidence of investors. On June 1, 2016, CSRC officially announced the administrative punishment to Xintai Electric Co. which made Dandong Xintai Electric Co. become the first one which was delisted because of financial fraud. This paper tries to do deep analysis on the major inducements and methods of financial cheating of Xintai Electric Co. so that we can find out some preventive means to reduce the occurrence of financial fraud to prevent the investors from unnecessary losing.
\end{abstract}

\section{Keywords}

Dandong Xintai Electric Corporation Limited, Listed Company,

Financial Fraud, Stock Market

\section{Introduction}

In the 20 years since the establishment of China's securities market, financial fraud of listed companies to deceive investors and regulators often occurs. In 2001, Guangxia (Yinchuan) Industry Co. revealed an increase of 178 million Yuan in profits by financial fraud in 1999 and an increase of 567 million Yuan in profits by the same way. In 2006, Guangdong Kelon Electrical Holdings Co. revealed an increase of 1200 million Yuan in operating income and an increase of 120 million Yuan in profits by falsification of accounting surpluses. In 2013, Wanfu Biotechnology (Hunan) Agricultural Development Co. revealed an increase in profits from 2008 to 2012 by falsification of ac- 
counting surpluses.

As we all know, financial fraud can not only cause financial information distortion of listed companies which may lead investors to make bad judgments and decisions based on false information, so that investors will take losses in investments, but also let bad money drive out good money, which may lead to reverse market resources allocation. Meanwhile, it will cause serious economic and legal consequences for related agencies. Therefore, it's important and necessary to do deep analysis on the major inducements and methods of financial cheating of listed companies so that we can find out some preventive means to reduce the occurrence of financial fraud to prevent the investors from unnecessary losing.

\section{Theory and Hypothesis Development}

\subsection{Principal-Agent Problem}

The principal-agent problem, in political science and economics, (also known as agency dilemma or theory of agency) occurs when one person or entity (the agent) is able to make decisions on behalf of, or that impact, another person or entity (the principal). The problem arises where the two parties have different interests and asymmetric information (the agent having more information), such that the principal cannot directly ensure that the agent is always acting in his (the principal's) best interest, particularly when activities that are useful to the principal are costly to the agent, and where elements of what the agent does are costly for the principal to observe [1]. Often, the principal may be sufficiently concerned at the possibility of being exploited by the agent that he chooses not to enter into the transaction at all, when it would have been mutually beneficial: a suboptimal outcome that can lower welfare overall.

Common example of this relationship is the relationship between corporate management (the agent) and shareholders (the principal). Due to the corporate management is responsible for running the company, so that they know the real financial data and the actual situation of the company. In the meantime, most shareholders do not participate in the actual operation of the company. Therefore, the only way they can know about the conditions of their company's operation is checking the information released by corporate management. In this case, if the orientation of the interests of company management team (the agent) and company owners (the principal) are inconsistent, it will be easy to cause financial fraud.

\subsection{GONE Theory}

GONE theory was proposed by Bologua in 1993 [2]. Bologua considers that financial fraud is caused by four factors include G (Greed), N (Need), O (Opportunity) and E (Exposure).

$G$ (Greed) factor means the level of moral of individual. Ethic is a kind of psychological factors for the cheater. And it plays a very important role in human's behavior and cognition. It shows as an individual value judgment which will influence people deeply when they are thinking about whether they will do something or not. Fraud often have 
poor moral consciousness or have a negative value judgment in moral awareness. In the presence of such bad morals, financial fraud has become a kind of behavior consistent with its values and that's why fraud happens at last.

$\mathrm{N}$ (Need) is called "motivation" factors, which is the key reason of the improper accounting behavior. Proper motivation of accounting behaviors appropriate accounting practices, in the meantime, improper motivation of accounting behaviors inappropriate accounting practices under the external stimulus, such as financial fraud. "Need" is the direct cause of financial fraud. The need for capital, the need for improving stock price and the need for individual benefit, may lead the company managers to cheat. Because of the high cost of information in capital market, investors cannot identify whether the information given by listed companies is real or not without high cost of exchange. Therefore, the "Need" of financial fraud persists in listed companies.

O (Opportunity) is relevant to the corporate governance structure of company and the power of supervision. Good corporate governance structure, first from the reasonable structure. Ownership structure determines the tone of corporate governance structure and framework [3]. A reasonable ownership structure is the foundation for manager to maximize stakeholder's interests and the fundamental guarantee for eliminating the conflicts of internal people. A reasonable ownership structure can also ensures the implementation of specific arrangements which made by Board of Directors, the Supervisory Board or others. Excessive concentration of ownership will produce the effect of expropriation, which may show up as the conflicts of interest between the controlling shareholder and non-controlling shareholder which will make the controlling shareholder sacrifice the non-controlling shareholder for their own benefits. Hence, the higher the concentration of ownership, the greater the effect of expropriation, the more likely the financial fraud happen [4].

The power of supervision is relevant to the independence of related intermediaries. As we all know, every financial statement cannot be allowed to be announced without audit by CPA. As the last process of the project for defending financial fraud, CPA plays a very important role in protecting against financial fraud of listed companies. If CPA's position is not independent enough, it will give listed company opportunity to cheat investors. Therefore, if managers with power are not properly monitored by a complete system with a reasonable corporate governance structure and an independence related intermediary, they will have the opportunity to obtain benefits through illegal accounting practices.

E (Exposure) means the possibility of financial fraud being discovered and disclosed and the level of punishment for cheating, which will deter potential cheaters. Fraud is deceiving and conceal. The possibility of financial fraud being discovered and the level of punishment for cheating will influence the decision made by people who want to fraud. On the one hand, the higher the possibility of financial fraud being discovered and disclosed, the lower the possibility of financial fraud happening. On the other hand, the lower level of punishment for cheating, the higher the possibility of financial fraud happening. 
All in all, G (Greed) and $\mathrm{N}$ (Need) are associated with the individual acts, and $\mathrm{O}$ (Opportunity) and $\mathrm{E}$ (Exposure) is more relevant to the environment. It means that if a manager with heart of greed and need in money has a chance to corrupt and make sure that the move will not be found, the corruption will happen. In order to effectively prevent the occurrence of financial fraud, actions will be taken to regulate the areas represented by these four factors.

\subsection{Theory of Fraud Risk Factor}

The theory is developed on the basis of GONE theory by Bologua, which is by far the most perfect form of fraud risk factor theory. Theory of fraud risk factor is the foundation of establishment for fraud-auditing. It divides the fraud risk factor for individual risk factors and general risk factors. Individual risk factor refers to the person, including moral and motivation. General risk factor refers to the factors controlled by intermediaries or entities, including the chance of fraud, the probability of fraud being found and the level of punishment for cheating. When the combination of individual risk factors and general risk factors and is considered favorable by fraud, fraud can occur.

Table 1 provides the association between GONE theory and Theory of fraud risk factor.

\section{Case Study}

\subsection{Case Introduction}

Listed companies are important participants in the securities industry, Information disclosure of listed companies is an important investment investor references. Therefore, these information should be completely reliable. China's securities market was established late so that the laws and regulations are not sound and there are still a lot of shortcomings and irregularities in information disclosure and governance structures, such as incomplete information disclosure, financial fraud, and so on. Many fraud cases of listed companies such like Guangxia and Kelon often occur, which caused huge losses to investors, severely disrupted the securities market order in China, and even raised doubts about China's financial market moral standards at home and abroad. Most of the fraud are similarities in means and motivation, which reflects that China's stock market system is not perfect, and monitoring is not in place.

Table 1. The association between GONE theory and theory of fraud risk factor.

\begin{tabular}{ccc}
\hline \multicolumn{2}{c}{ Theory of fraud risk factor } & GONE theory \\
\hline \multirow{2}{*}{ Individual risk factor } & Morality & G (Greed) \\
& Motivation & N (Need) \\
Chance & O (Opportunity) \\
General risk factor & The probability of fraud being found & E (Exposure) \\
& The level of punishment for cheating &
\end{tabular}


Dandong Xintai Electric Co. was established in 1960 and started to apply for IPO in 2011. Main products of the company are performance optimization equipment, such as Energy-efficient power transmission and transformation equipment and reactive power compensation device. In 2014, Dandong Xintai Electric Co. became a listed company.

On June 1, 2016, An announcement of Dandong Xintai Electric Co. claimed that the company would receive CSRC's punishments due to financial fraud including: 1) A warning and a fine of 8.32 million Yuan for the company; 2) A warning and a fine of 8.92 million Yuan for the Chairman Wen; 3) A warning and a fine of 600,000 Yuan for the Chief Accountant Liu; 4) A ban against Wen and Liu entering the stock market; 5) Warnings and fines for the other company manager; 6) The company's stock would be delisted from the market.

\subsection{Analysis of Financial Fraud of Dandong Xintai Electric Co.}

Dandong Xintai Electric Co. will become the first one which was delisted because of fraudulent issuance. The irregularities of the company mainly including illegal adjustments of accounts receivable and illegal write-down of material costs to inflate profits.

\subsubsection{Illegal Adjustments of Accounts Receivable}

As the accounts account receivable balance is too large, in order to make the company listed, Liu suggested to Wen that reducing accounts receivable by external borrowing at the end of the accounting period.

There were three specific methods the company use to adjust its accounts receivable. The first method is that after Wen borrowed money from others, a teller would do both cash withdrawals and cash payments at a bank counter. To be noticed, when the teller were filling out a cash payment form, he would directly fill in the clients company name in the payment column which would make the money that Wen borrowed became the money that the clients company pay back. After the end of report period, Wen would return the money.

The second method is that after Wen borrowed money from the other company, the company would send a bank draft which was endorsed by the clients company to Wen. This method could also reduce the number of receivable.

The third method is reducing the number of receivable by counterfeiting bank bills and payment. Because of the large number of interest expenditure, Wen started to counterfeit bank bills and payment by computer to make a decrease in accounts receivable from 2013.

By using these methods, the company made a decrease of 102 million Yuan in accounts receivable which cause a decrease of 6.59 million Yuan in bad-debt provisions and an increase of 102 million Yuan in net cash flow from operating activities in 2011. The next year, the company made a decrease of 121 million Yuan in accounts receivable and other receivables which cause a decrease of 7.26 million Yuan in bad-debt provisions and an increase of 33.84 million Yuan in net cash flow from operating activities by the same ways. 


\subsubsection{Illegal Write-Down of Material Costs to Inflate Profits}

According to the prospectus, The company's average price of purchasing of silicon steel sheet was 14,905.8 Yuan per ton, and the amount of purchasing was 6310.00 tons in 2012. But data from the China Steel NET showed that the lowest price of purchasing of silicon steel sheet was more than 17,000 Yuan per ton and in 6 months before the price was more than 19,000 Yuan per ton.

Though assuming that the average price of purchasing of silicon steel sheet was 19,000 Yuan per ton, the company's purchasing average price was more than $4000 \mathrm{Yu}$ an lower than the market price. And the real total amount of purchasing of silicon steel sheet should be 120 million. This number was 25 million Yuan more than the number that was revealed in prospectus which means that the real profits of the company in 2010 was at least 25 million Yuan lower than the number of profits which was revealed in prospectus. The prospectus showed that the company generated 59.03 million Yuan in profits in 2010 , which means that more than $40 \%$ of the net profits shown by its report was faked.

By the way, 1/5 of its net profits was caused by tax incentives. As the company was welfare enterprises and high-tech enterprises, according to the related policy, it can get discounts in VAT, income tax, real estate tax and land use tax which made the profits sound and stable.

Table 2 provides the numbers of tax discounts the company got from 2009 to 2011.

\subsection{Reasons of the Financial Fraud of Dandong Xintai Electric Co.}

Based on the principal-agent theory, due to the information asymmetry between the consignor and the consignee, so that financial fraud is so hard to be found. In the meantime, the greed and being lack of legal awareness of the company management team has led to a serious financial fraud. Author will analyze the reasons of the financial fraud from 4 aspects, including incomplete capital market system, incomplete regulatory enforcement system, low violation cost and Lack of legal consciousness and greed of the company management team.

\subsubsection{Incomplete Capital Market System}

There are still many defects in the current structure of China's capital market system. For examples, the new distribution system is not perfect, resulting in new problem appeared such as reporting high prices during the period of book-building for the qualification of placing new shares; Intense growth of IPO earnings and super-raising phenomenon. Meanwhile, the rule in securities law that the stock of the listed company which losses in three consecutive years will be suspended make some company's man-

Table 2. The numbers of tax discounts the company got from 2009 to 2011.

\begin{tabular}{cccc}
\hline Years & 2009 & 2010 & 2011 \\
\hline Tax discount & 10.71 million Yuan & 13.48 million Yuan & 13.60 million Yuan \\
Tax discount/Profits & $25.49 \%$ & $22.85 \%$ & $24.26 \%$ \\
\hline
\end{tabular}


ager and stakeholders has motivation to try everything including financial fraud to prevent their stocks from being suspended or terminated. In the meantime, capital market institutions are unable to restrain the management of listed companies, so that the capital market became a tool for raising money of listed companies.

\subsubsection{Incomplete Regulatory Enforcement System}

The process before the listing of a company including audit from CPA, recommendation from sponsor, checking from lawyer and the approval from CSRC. However, perfect system will lose its function if it cannot be executed strictly. In the process before the listing of Dandong Xintai Electric Co., the CPA didn't find the problem in the financial statement, the security company didn't do the verification and due diligence investigation carefully, the lawyer didn't do the check and verification and CSRC didn't find the problem as well, resulting in the successful listing of Dandong Xintai Electric Co. in 2014.

It is worth mentioning that accounting firms are the subject of audits of listed companies, however, supply and demand imbalance in the market that the market is glutted with audit services, so that listed companies have strong bargaining power. Therefore, most accounting firms rely on lower prices to drum up business. In order to control the cost, most accounting firms prefer to reduce the audit procedures which will lead to a quality reduction of their services and this may be an important reason that the problem of the company could not be found before its listing.

\subsubsection{Low Violation Cost}

Due to the incomplete laws in China, the illegal private cost are low, which might induce enterprises to do something like financial fraud to seek illegitimate interests. From the case of Wanfu Biotechnology (Hunan) Agricultural Development Co which was revealed a financial fraud before, the company was only punished by a fine of 300,000 Yuan. The most important thing is not to let the company delisted, which made the penalty lost its effect of warning to similar event. All in all, considering both the benefit and the cost of violation, the benefit is far more than the cost, which lead to more and more events of financial fraud occur.

\subsubsection{Lack of Legal Consciousness and Greed of the Company Management Team}

Based on the theory of fraud risk factor, individual risk factor refers to the person, including moral and motivation and general risk factor refers to the factors controlled by intermediaries or entities, including the chance of fraud, the probability of fraud being found and the level of punishment for cheating.

After talking about the general risk factor controlled by intermediaries or entities, the individual risk factor controlled by person should not be ignored. In this case, the Chairman Wen and the other managers of Dandong Xintai Electric Co. were greed and lacking in legal consciousness which made them just do everything they can do to maximize their interests but didn't realize the serious consequence caused by their behaviors. 


\section{Suggestion}

In this case of the financial fraud of Dandong Xintai Electric Co. although the company management team and related intermediaries were punished by CSRC, it cannot recoup the investors' losses. These events let us figure out that investing is risky and we should be cautious to make invest decision. And it also means that actions including perfecting the relevant laws, enhancing law enforcement efforts, strengthening independence of the related intermediaries and strengthening the occupational ethics of the jobholders, are required to make company management team provide real and reliable information about the company, and to make the other related intermediaries such as accounting firms, security firms and law firms do their work dutifully and discreetly.

\subsection{Perfecting Relevant Laws}

The first step need to take is standardizing the compensation mechanism for investors. In China, because of the securities market "caveat emptor" principle, investors cannot get compensation no matter how much they lost. It is unreasonable for investors to bear the loss caused by institutional defects or ethical issues.

The second step need to take is enhancing supervision. Regulators must strengthen its supervision of listed companies in various ways, develop a comprehensive monitoring system to monitor the behavior of managers strictly, improve transparency in information disclosure of listed companies to make listed companies achieve reliable public disclosure of financial information and strive to clear the vacuum of regulatory [5].

The third step need to take is improving the system and relevant laws and regulations about information disclosure. It is necessary to track and verify the announcement and disclosure of information of listed companies timely. Therefore, a dynamic information disclosure supervision mechanism is needed to determine truthfulness of accounting information and protect investors against interference and false information.

\subsection{Enhancing Law Enforcement Efforts}

In the foreign mature financial market, when a listed company being found that making the fake, the punishment that the manager fear most is to compensate the securities purchasers' loss which may squander their inherited property and ruin their family. This method can effectively prevent the occurrence of financial fraud of listed companies. But in China, the penalties for listed company are more focused on administrative punishment, and less accountability for civil liability for violations of the securities market, which make listed companies and related intermediaries can still get generous benefits after being punished.

According to analysis, the probability of the reveal of financial fraud of listed company is less than $50 \%$. According to the relevant laws and regulations, maximum fines for the financial frauds is less than 5 million Yuan so that the opportunity cost of financial fraud is less than 2.5 million Yuan.

Therefore, the first step need to take is to increase the penalties for violations of listed 
companies. All its illegal gains should be fined. In the meantime, we should emphasize the civil liability that listed companies with financial fraud should bear and Increase the intensity and the scope of compensation to investors. By heavy fines to increase the potential cost of financial fraud, to form a reasonable judgment of listed company to reduce the incidence of financial fraud.

The second step need to take is perfecting the delisting system. In the foreign mature financial market such as USA, Japan and Europe, delisting companies accounted for larger numbers of total listed company. On the one hand, for various reasons, China's securities market has been unable to achieve smooth delisting mechanism which makes a large number of poor company on the stock market. Therefore, lack of perfect delisting system seriously hamper the stock market to play a role in optimizing the allocation of resources which is not good for the development of the capital market. On the other hand, the current listing system make listed company become scarce and a devastating. It means that when a company is going to delist, there will be a big amount of companies that would like to carry out reorganization of assets with it to achieve the objectives of listing through buying a shell which is a practice quite popular several years ago in Chinese Mainland.

As shown above, it is necessary to standardize delisting mechanism. For example, the quantity standards in the current delisting system are too simple that make the system cannot restrict listed company effectively. Based on this, China should learn from foreign experience in the stock market such as developing the quantity standards to manage the dividend distribution, the number of non-institutional shareholders and the amount of net assets to objectively reflect the real business and financial conditions of listed companies.

\subsection{Strengthening Independence of Related Intermediaries}

In the case of the financial fraud of Dandong Xintai Electric Co., the related intermediaries were all punished by CSRC because of failure to implement its faithfulness and obligations.

The verification of intermediaries necessary before offerings, every company which want to be a listed company should accept the audit from CPA first. CPA have the fullest possible access to first-hand information of listed companies which make them most likely to find out the financial problem of the company. Thus, accounting firms play an irreplaceable role in detect and deter financial fraud of listed companies. However, intermediary services are purchased by the listed companies, it is difficult to ensure the independence during the intermediary services. Intermediaries are more likely to join in their evildoings due to the interests.

It's necessary to change the current cooperation mode built by the listed company and the intermediaries. The CRSC or other regulators can try to select the appropriate intermediary for listed companies based on some criteria. Choosing audit firms providing higher level audit services for companies with high risk, also, exploring a new mode to calculate audit fees, rewarding the firm which discover and reveal a significant 
business or financial fraud to enhance the independence of the audit and improve the audit quality [6]. Strengthening the independence of related intermediaries and forming strong regulatory mechanisms have a positive sense to protect against financial fraud of listed companies.

\subsection{Strengthening the Occupational Ethics Related Jobholders}

Financial fraud of listed company means the negligence of accounting, auditing, sponsor and lawyer and also means the lack of professional ethics of related jobholders. We should strengthen the occupational ethics of related jobholders and the duty of the managers. Actions to strengthen the construction of professional ethics and improve professional competence in practice are necessary to be taken to prevent financial fraud at its root [7].

The CPA's occupational ethics will affect the function of accounting inevitably the display, and also will affect the information user's decision-making which may affect the entire society, therefore, strengthening the personnel occupational ethics of related jobholders, is very meaningful for the entire society. The accounting information distorts has become a serious problem puzzles the whole accounting profession. Establishing the occupational ethics system and building a good accounting environment are important for preventing against financial fraud of listed companies.

At first, we should establish complete moral education system. Secondly, establishing complete internal supervision system is also necessary. At last, we should create right cultural air to educate and cultivate related jobholders about the professional ethics in a good environment.

\section{Conclusions}

After the CSRC announced the punishment to Dandong Xintai Electric Co. and Pingan Security Company, this event came to an end and gradually disappeared from public sight. But the discussion caused by this matter has not subsided; some have even become worse. It is apparent that the shock of this event to investors and the other people is not over. It not only sounds the alarm for many listed companies, but also reminds the related intermediaries that financial fraud may bring short-term benefits easily but also can harm others and themselves eventually. Faking the data on the financial statement cannot take care of the problem - the confronting problem of the listed company effectually, but on the contrary, it will make the level of financial fraud higher and higher which may trigger big financial crisis and deal a severe blow to listed companies and related intermediaries. Dandong Xintai Electric Co. was the first one which was delisted because of financial fraud.

This article is trying to make a review of this case and conclude the methods that Dandong Xintai Electric Co. used to cheat. And on this basis the author is trying to give some preventive measures, such as standardizing the compensation mechanism for investors, enhancing supervision to listed company, improving the system and relevant laws and regulations about information disclosure, enhancing law enforcement efforts, 
enhancing law enforcement efforts, strengthening independence of related intermediaries and strengthening the occupational ethics related jobholders. All of the actions mentioned above are needed to effectively suppress the frequent occurrence of financial fraud which is the meaning of this article.

\section{References}

[1] Ndofor, H.A., Wesley, C. and Priem, R.L. (2015) Providing CEOs with Opportunities to Cheat the Effects of Complexity-Based Information Asymmetries on Financial Reporting Fraud. Journal of Management, 41, 1774-1797. http://dx.doi.org/10.1177/0149206312471395

[2] Bologna, G.J., Linclquist, R.J. and Wells, J.T. (1993) The Account's Handbook of Fraud and Commercial Crime. John Wiley \& Sons, New York.

[3] Chen, G., Firth, M., Gao, D.N. and Rui, O.M. (2006) Ownership Structure, Corporate Governance, and Fraud: Evidence from China. Journal of Corporate Finance, 12, 424-448. http://dx.doi.org/10.1016/j.jcorpfin.2005.09.002

[4] Warfield, T.D., Wild, J.J. and Wild, K.L. (1995) Managerial Ownership, Accounting Choices, and Informativeness of Earnings. Journal of Accounting and Economics, 20, 61-91. http://dx.doi.org/10.1016/0165-4101(94)00393-J

[5] Beasley, M.S., Carcello, J.V., Hermanson, D.R. and Lapides, P.D. (2000) Fraudulent Financial Reporting: Consideration of Industry Traits and Corporate Governance Mechanisms. Accounting Horizons, 14, 441-454. http://dx.doi.org/10.2308/acch.2000.14.4.441

[6] Abbott, L.J., Park, Y. and Parker, S. (2000) The Effects of Audit Committee Activity and Independence on Corporate Fraud. Managerial Finance, 26, 55-68. http://dx.doi.org/10.1108/03074350010766990

[7] Ferrell, O.C. and Fraedrich, J. (2015) Business Ethics: Ethical Decision Making \& Cases. Nelson Education, Toronto.

\section{Submit or recommend next manuscript to SCIRP and we will provide best service for you:}

Accepting pre-submission inquiries through Email, Facebook, LinkedIn, Twitter, etc.

A wide selection of journals (inclusive of 9 subjects, more than 200 journals)

Providing 24-hour high-quality service

User-friendly online submission system

Fair and swift peer-review system

Efficient typesetting and proofreading procedure

Display of the result of downloads and visits, as well as the number of cited articles

Maximum dissemination of your research work

Submit your manuscript at: http://papersubmission.scirp.org/ 